\title{
sciendo
}

Ethics \& Bioethics (in Central Europe), 2019, 9 (1-2), 65-69

DOI:10.2478/ebce-2019-0009

\section{Animalization of language, therefore death of a man}

\section{Tomasz Turowski ${ }^{1}$}

\begin{abstract}
In the article, I try to emphasize that our way of using language affects moral decisions and attitudes. As we think as we speak and simultaneously, we act. By using chauvinistic language, first of all, we simplify our reality; secondly, we push those beings that we define in the language to the margins. I think that our language is homocentric and therefore leads us to speciesism.
\end{abstract}

Keywords: language, ethics, morality, animal rights, animal welfare, interest, speciesism, acts of speech, performatives

From Nietzsche's time, one can speak about the idea of killing the idols in philosophy. After all, no one, other than the author of Zarathustra announced the death of God, which in fact was not only the first unveiling of a nihilistic vision of a new way of valuing, but was supposed to have a global dimension above all else. Nietzsche, ultimately, was not just about removing ethics from the concept and sense of sanctity, but above all about setting free morality from fossilized, traditional patterns that drove man down like the debris of conventional expressions. As we know, Nietzsche first used the slogan of the death of God in his Gay science (1882) in the opinion of many scholars and interpreters and this work immediately preceded Zarathustra (1883-1885) and gave a new character to Nietzsche's philosophy. Almost all readers of the author of The birth of tragedy know the famous article 125 about the madman who, in the broad daylight of the market, announces the death of God and the fall of ideals which mankind has believed in so far and to whom and to which he entrusted his fate. However, it is worth emphasizing that the earlier passage, fragment number 108, where we find it is important: "God is dead: but given the way of men, there may still be caves for thousands of years in which his shadow will be shown. - And we - we still have to vanquish his shadow, too" (Nietzsche, 1974, p. 167). The essence of the fragment is to emphasize the fact that with the degradation of the eidolon, the universal and species belief in its duration is not lost. That is why the question: "When will all these shadows of God cease to darken our minds? When will we complete our de-deification of nature? When may we begin to naturalize humanity in terms of a pure, newly discovered, newly redeemed nature?" (Nietzsche, 1974, pp. 168-169) is very legitimate.

Nietzsche's problem in The gay science, and at that time was that the death of the deity alone was not enough to establish a new way of valuating to go beyond good and evil. Nietzsche saw this critical consequence a year after the publication of The gay science, while working on his opus vitae: Thus spoke Zarathustra. It is in this work that the author noticed that in order to the fulfill his plan besides the death of a god, a man's death is still needed, or at least his transgression, the revaluation of his previous forms. Hence, Zarathustra in many places instructs recipients about the necessity of transformation, about transgression. For example, we read: "When Zarathustra came into the next town, which lies on the edge of the forest, he found many people gathered together in the market place; for it had been promised that there would be a tightrope walker. And Zarathustra spoke thus to the people: "I teach you

\footnotetext{
${ }^{1}$ University of Zielona Góra, Institute of Philosophy, Zielona Góra (Poland); email: t.turowski@ifil.uz.zgora.pl
} 
the overman. Man is something that shall be overcome. What have you done to overcome him? All beings so far have created something beyond themselves; and do you want to be ebb of this great flood and even go back to the beasts rather than overcome man? What is the ape to man? A laughingstock or a painful embarrassment. You have made your way from worm to man, and much in you is still worm" (Nietzsche, 1982, p. 124).

I began my paper with a short history of reminding us how the concept of the death of values and the forces merging them came to appear in philosophy. Nietzsche's genealogy of values has survived in the writings of thinkers that are normally included in postmodernism, such as Jacques Derrida, and this is particularly evident in the works of Michel Foucault, whose statements about the "death of man" became slogans of the second half of the twentieth century. Foucault and his conviction "that man is only a recent invention" (Foucault, 2005, p. xxv) and now we are dealing with the exhaustion of its essential capabilities, although drawn from the thought of the author of Zarathustra, it made a rapid and dizzying career.

So, Foucault, and the previously mentioned Nietzsche, as well as Wittgenstein and Heidegger saw a change in anthropocentrism in a different way of using language. In his Treatise, Ludwig Wittgenstein emphasized that the rules of language are correlated with reality, in such a way that they order discourse on $t$ what and how to express it. According to Wittgenstein, problems of philosophy in general come from the fact that the "logic of our language is misunderstood. The whole sense of the book might be summed up in the following words: what can be said at all can be said clearly, and what we cannot talk about we must pass over in silence" (Wittgenstein, 2001, p. 3). Any philosophical problem can be reduced to a language problem, to that; how to use a language. In a similar way thought the young Heidegger ${ }^{2}$, which in the period preceding Sein und Zeit saw that language and its rules refer to being, in such a way that they speak, that is, express the discourse that Heidegger says must reveal the meaning of being. Understanding is one of the ways of being and therefore "are characterized equiprimordially by discourse" (Heidegger, 2001, p. 172). Discourse for Heidegger is not just the use of language, verbalization and articulation, but it is "existentially equiprimordial with state-of-mind and understanding. [...] Discourse is the Articulation of intelligibility. Therefore it underlies both interpretation and assertion" (Heidegger, 2001, pp. 203-204).

Since Nietzsche's time and his discovery of the "lie of words" by Wittgenstein, Heidegger and Foucault, most philosophers have agreed that discourse and language are not just a way of expressing and communicating thoughts, but their role is fundamental in philosophy in general. I think that this phenomenon was aptly described by the author of the Logico-philosophical treatise: "The limits of my language mean the limits of my world" (Wittgenstein, 2001, p. 68, thesis 5.6). What's more, language does not only affect modern epistemology or ontology, but also moral philosophy, in ethics particular.

The death of man in my perspective, therefore in conviction, that the philosophy of morals is oriented towards the ethics of animal rights or animal welfare, and thus referring to proanimal philosophy, takes the form of a twilight of anthropocentrism or simply the exhaustion of the possibilities of traditional ethics and its anthropological foundations. The twilight of anthropocentric ethics is a phenomenon noticeable on the horizon of a certain inadequacy of traditional life ethics, abusing abstract absolutism, which is the source of a hypocrisy not too aware of traditional ethics, pushed into unconscious inconsistency. Ethics for now is too general and abstract if it is applied in the form of institutionalized codes.

The issue for me here is important in the matter of fundamental linguistic reorientation. On the one hand, the above-mentioned philosophers of discourse led to the release of language from the power of metaphysics, and on the other hand led to a new way of understanding

\footnotetext{
${ }^{2}$ The biographical-philosophical division of Heidegger's thinking derives from Theodore Kisiel's book The Genesis of Heidegger's "Being and Time” (Kisiel, 1993, p. xiii; see also Leśniewski, 2010, p. 8).
} 
anthropology. Nietzsche taught the demise of every value, thus revealing omnipresent nihilism, besides the death of God, we have the death of the current form of being a human being. For Foucault, man turns out to be dead, residual and recent. In all of this, working with discourse as an all-powerful interpretation of the human and non-human world. There is no doubt that nowadays in moral philosophy is not only about what we say, but above all how. The language not only operates with valuative semantics but, above all, it defines and justifies it.

Therefore the problem, concerns the language of value-making articulation and its impact on the practical aspect: as we speak, this is how we behave and how we act in the world. We often hear animated terms in relation to our species, which aim to depreciate the concept of man and, in general, the importance being of human. For example if we want to offend someone, we use the words: "you're a pig"; "a wolf in sheep's clothing"; "as blind as a bat"; "at snail's pace"; "fight like cat and dog"; "a snake in the grass"; "a lame duck"; "you eat like a pig"; "you looks like a pig"; "you fat cow"; "porcine snout"; "you lie like a dog"; "you stupid donkey"; "stubborn as a mule"; "free as a bird"; "fake like a fox", and primum inter pares: "you act like an animal". Of course, next to invective, we have terms considered ennobling, or higher rank compliments: "healthy as a fish"; "hard-working like an ant"; "smart as a fox"; "as faithful as a dog"; "agile like a cat"; "mild as a lamb", etc. In both cases (pejorative and positive terms) the list is long, but the bottom line is that both lists have an influence on anthropology as such, projecting into a dictionary (everyday language). The point is that the transfer of concepts referring to the animal world leads to the fact that these concepts become pejorative.

In pro-animals philosophy it was noticed relatively late and by a circuitous route: through linguistic deconstruction ${ }^{3}$, nevertheless, if I were to attempt what is a common feature or even a paradigm in a fairly antagonized pro-animal philosophy, then it is definitely a deconstruction, or weakening the anthropocentric option in ethics. From Peter Singer to the proposal of Francione, the whole moral philosophy, in the interest of which is animal ethics, regardless of whether it is a welfarist (reformist) or legal (abolitionistic) option, is convinced of the necessity of abolition or rejection of anthropocentrism.

It should be noted that anthropocentrism itself is relatively often simplified and criticized in pro-animal philosophy. The authors usually show the negative implications of the practicality of adopting anthropocentrism, which shaped the moral tradition of the West. In the writings of Singer, Regan, Ryder, or Francione, they are rife with interpreting anthropocentrism in a value spirit: by elevating the value (for example: legal and natural dignity) of man and only this species, species of homo sapiens, other - different species were depreciated in value (Bekoff, 1998, pp. 66-68). In itself, this is not wrong, such interpretations of traditional Western philosophy are valuable and for the subject of pro-animal philosophy itself, it is important. However, I cannot fail to notice that the understanding of anthropocentrism (and also the interpretation of the all anthropological criterion) within "homocentrism, human chauvinism, speciesism, and human-centered ethics" (Bekoff, 1998, p. 66), is basically too sketchy. In my opinion, in this way, the positive aspects of anthropocentrism are blurred, which often results in unnecessary equating of incomparable beings. Therefore, it is important to emphasize significant interspecies differences, the recognition of which leads to the beauty of the human point of view of nature and non-human beings, therefore we do not have "the basics to expect that human relationships with other animals can duplicate the interpersonal dimension. These are not just interpersonal relationships. This is their special value. Trying to treat them in the same way would be flattening and not using their potential" (Gzyra, 2018, p. 29). Anthropocentrism can have many positive implications, such as defining interspecies

\footnotetext{
${ }^{3}$ For an example please look at J. Derrida's L'animal que donc je suis (à suivre) from 1999. I used the English translation The animal that therefore I am (More to follow), from: The animal that therefore I am, transl. D. Fordham, New York University Press, New York 2008.
} 
relationships when adopting the anthropological criterion as a starting point for the way they are determined and, consequently, capturing the moral status of non-human beings.

Pro-animal philosophy often uses the anthropological criterion, and contemporary propagators of animal rights and interests, including Alasdair Cochrane who in his Animal Rights Without Liberation, confirms a fairly well-known fact that the starting point for determining the rights and interests of animals is the somehow understood anthropological criterion. "In this sense, then, animal rights are often considered to be analogous to human rights. For human rights do not demand that we stop beating our slaves, or that we regulate the ways woman are trafficked more humanely; instead they demand that such forms of exploitation be abolished and victims liberated" (Cochrane, 2012, p. 3). Of course this is no new point of view, because in the theory of animal rights it was formulated in 1983 by Tom Regan, whereas in the trend of respecting interests (equal consideration of interests) in the 1970s by Peter Singer. Regardless of the difference between Tom Regan, and the author of Animal liberation one thing is common - to emphasize the existence of rights (Regan), interests (Singer), these philosophers refer to some vision of man and his moral status. Regan carries out an analysis of moral powers, emphasizing the commonality of natural rights, which as such are not available only to representatives of homo sapiens. Peter Singer, while delineating the principle of equal consideration of interests in Animal liberation, proposed the rejection (or weakening) of anthropocentrism, in favor of pathocentrism, while maintaining a weak version of the anthropological criterion.

The problem is the language of animal rights ethics, which, in the opinion of many opponents of this, leads to the "animalization" of philosophical discourse. Of course, in such a formulation you can find elements that defy the concept of homo sapiens, and it will be offensive. It is often said about the animalization of man, that is, his extremely amoral behavior. For example, the concept of animalization was used in the context of the Holocaust. Meanwhile, animalization in animal philosophy may be twofold: on the one hand, to refer linguistically to a fundamental change in value articulation, and on the other hand to attempt to develop a new animalistic language in the context of the death of man, in this case in the face of the collapse of traditional anthropology. Let us pay attention to the fact of the feminization of language, which served a better understanding of women's rights. In gender studies, the necessity of linguistic changes in relation to women has often been stressed. The main task of this linguistic reform was to lead to the evolution of thinking about women as those that even in men's language. To animalize language in pro-animal philosophy means to get rid of those terms deprecating us and the nonus. Human and non-human beings. Therefore, the departure from anthropocentrism must take place in the linguistic layer. Our ordinary, colloquial discourse everyday emphasizes the fundamental differences between people and animals. An animal is always an "it", it is neuter, devoid of sex and social function, it is beyond "he" and "she", it is not a personal pronoun, "it" is a thing. Our language "denies the similarity between human and non-human beings. We are not animals, primates or monkeys" (Dunayer, 2013, p. 9). Language enforces our anthropocentric attitude towards animals, causing our species to become accustomed to the fact that we are species-honored. A man dies, an animal only dies. Death of man is sanctity but this is only for human beings. Animals kick the bucket and that's all. Man passes away, animals only die. The main thing is that: our "language practice, promotes a false dichotomy between human and non-human beings. Separate vocabulary suggest opposing behaviors and attributes" (Dunayer, 2013, p. 9). Our language practice affects the normativity of the language, the assessment and implies behavior, often contempt for others. Such terms are of a performative character, because they have a causative role. These language usages accustomed us to hidden, subconscious assessments that play a role in our practice: we act as we think, think as we speak. In a sense, we act by means of words, and how we make them - we use it, it has meaning in our way of dealing with the world. 
The processes of animalization of language are inevitable as it was in the case of language feminization. When it was implemented its seemed linguistically clumsy and artificial, meanwhile we have already got used to these terms of the feminizing of language. This is, because human language - this Nietzschean tool of lies - has an amazing ability to update and assimilate changes in the dynamics of discourse, both colloquial and philosophical discourse. I think that interpretation is the main feature of our language, so perhaps a new hermeneutics of language should be developed, the task of which will be to create performatives for the ethics of animal rights. The language actualization here, is related to the evolution of moral principles and is a tool for social change.

By animalization and updating our language habits, we reflect on our attitudes towards animals in general. "Reflective self-referral of someone, who speaks or writes, to their own language is a component of research work in animal studies, more broadly - participation in a cultural animal return. New ways of making a language game, by creating statements related to animals arise, among others, as a result of this reflection" (Lagodzka, 2015, pp. 171-172).

\section{References}

BEKOFF, M. (ed.) (1998): Encyclopedia of animal rights and animal welfare. Westport, CT: Greenwood Press.

COCHRANE, A. (2012): Animal rights without liberation: Applied ethics and human obligations. New York: Columbia University Press.

DERRIDA, J. (2008): The animal that therefore I am. New York: New York University Press. DUNAYER, J. (2013): Gatunkowizm i język [Species and language]. In: Zeszyty praw zwierzat, $1(4)$, p. 8.

FOUCAULT, M. (2005): The order of things: An archeology of human science. London: Taylor and Francis e-Library.

GZYRA, D. (2018): Dziękuję za świńskie oczy. Jak krzywdzimy zwierzęta [Thank you for pig's eyes: How we harm animals]. Warszawa: Wydawnictwo Krytyki Politycznej.

HEIDEGGER, M. (2001): Being and Time. Oxford: Blackwell.

KISIEL, T. (1993): The Genesis of Heidegger's “Being and Time”. Los Angeles \& London: University of California Press Berkeley.

ŁAGODZKA, A. (2015): Zezwierzęcenie, zwierzątko i animalizacja języka [Animalization, animal and language animation]. In: A. Barcz \& D. Łagodzka (eds.): Zwierzęta i ich ludzie. Zmierz antropocentrycznego paradygmatu [Animals and their people: Measure the anthropocentric paradigm]. Warszawa: Wyd. IBL PAN, pp. 171-172.

LEŚNIEWSKI, N. (2010): Hermeneutyczny kontekst "wiedzy źródłowej" [Hermeneutical context of "source knowledge"]. Poznań: UAM.

NIETZSCHE, F. (1974): The gay science. New York: Random House, Inc.

NIETZSCHE, F. (1982): Thus spoke Zarathustra. New York: Penguin Group.

WITTGENSTEIN, L. (2001): Tractatus logico-philosophicus. London \& New York: Routledge. 